\title{
ANTIBACTERIAL ACTIVITY OF ETHANOLIC EXTRACT OF SANGKAREHO (Callicarpa longifolia Lam.) AGAINST Staphylococcus epidermidis
}

\author{
*Susi Novaryatiin, Asma'ul Ayuriska Sari, \& Evi Mulyani \\ Department of Pharmacy, Faculty of Health Science, Universitas Muhammadiyah Palangkaraya, RTA. Milono St. Km. I.5 Palangka Raya, \\ Indonesia \\ *e-mail : susi_novaryatiin@yahoo.com
}

\begin{abstract}
One of the plants believed as traditional medicine by the Dayak tribes in Central Kalimantan was Sangkareho (Callicarpa longifolia Lam.). This plant was usually used as traditional medicine by society in Puruk Cahu, Murung Raya Regency, Central Kalimantan and empirically believed could cure skin disease such as wound infection. This study was aimed to determine the antibacterial activity of ethanolic extract of Sangkareho (Callicarpa longifolia Lam). Antibacterial activity of ethanolic extract of Sangkareho was performed using disc diffusion technique, with four variations of concentration of $1 \%, 5 \%, 10 \%$, and $15 \%$. In this present study showed that ethanolic extract of Sangkareho has antibacterial activity against Staphylococcus epidermidis, wherein the resulting inhibition zone diameter were $7.3 \pm 0.8 \mathrm{~mm}, 8.3 \pm 1.2 \mathrm{~mm}, 10.5 \pm 0.5 \mathrm{~mm}$, and $12.2 \pm 0.7 \mathrm{~mm}$, respectively. Further research is needed to obtain an antibacterial activity of the fraction of Sangkareho.
\end{abstract}

Keywords: Antibacterial Activity, Staphylococcus epidermidis, Sangkareho (Callicarpa longifolia Lam.), Central Kalimantan

\section{INTRODUCTION}

Natural medicinal plants have long been known by the people of Indonesia even hundreds of years ago. In the past, a medical expert known as the physician made a concoction of medicine whose ingredients came from the forest. It is estimated that Indonesia has 30,000 plant species, of which around 9,600 species are known to have medicinal properties, and only 200 species have been used as raw materials in the traditional medicine industry (Hapsoh \& Hasanah, 20II).

Kalimantan is an island in Indonesia that is famous for its rich biodiversity. Not only that, the wealth of traditional medical knowledge by using plants that are passed down orally from generation to generation to native ethnic groups in Kalimantan is also very much. Unfortunately, this knowledge is not documented and it is feared that it will erode along with the loss of natural habitat and the extinction of medicinal plants, especially forest plants due to excessive land exploitation and conversion (Noorcahyati, 2012).

Traditional herbs in indigenous ethnic Borneo are generally still in a simple form. Raw materials taken from nature after cleaning are usually used directly in fresh form by soaking or boiling and then drinking or bathing. Some are processed by mashed and crushed or heated in a leaf package. If the ingredients or raw materials for treatment are not directly used, then the ethnic groups in Kalimantan do the drying and stored and use if necessary (Handayani et al., 2015).
Central Kalimantan is one of the largest provinces in Indonesia that has a wealth of various types of plants, mammals, birds, reptiles, and so on. This province is the origin of various medicinal plants. One of the plants that are believed to be the traditional medicine by the Dayak tribe in Central Kalimantan is the Sangkareho plant (Callicarpa longifolia Lam.). This plant is usually used as traditional medicine by the Puruk Cahu community of Murung Raya Regency, Central Kalimantan Province and is empirically believed to be able to treat skin problems such as wound infections.

Wounds are damage to the anatomical structure of the skin which causes skin disorders. Staphylococcus epidermidis is one of the species of the genus Staphylococcus which is most commonly found in clinical interests and often causes infection in wounds. These bacteria are Gram-positive bacteria and include Staphylococcus with negative coagulation. Most of these bacteria are normal flora of the skin and human mucous membranes (Jawetz et al., 20l4). This study was aimed to determine the antibacterial activity of ethanolic extract of Sangkareho.

\section{MATERIALS AND METHODS}

\section{Materials and Equipment}

The materials used in this study were ethanolic extract of Sangkareho, S. epidermidis ATCC 12228, blank antibiotic disc, clindamycin, McFarland 0.5 standard, Brain Heart Infusion (BHI) medium, Blood Agar Plate (BAP) medium, 
Mueller Hinton Agar (MHA) medium, aquadest, ethanol $96 \%, \mathrm{NaCl} 0.9 \%, \mathrm{H}_{2} \mathrm{SO}_{4} 1 \%$, and $\mathrm{BaCl}_{2} 1 \%$. The equipment used includes percolator, rotary evaporator, laminar air flow, autoclave, and incubator.

\section{Methods}

Sangkareho (Callicarpa longifolia Lam.) was collected from Bahitom Village, Puruk Cahu, Murung Raya Regency, Central Kalimantan. The leaf part of Sangkareho was washed thoroughly with tap water, shade dried, powdered using a blender and stored. Dried powders of Sangkareho were extracted with ethanol $96 \%$ using Percolator's apparatus. The advantage of the percolation method that it was easy, simple and the risk of impurity is very small because it uses exhaustive extraction at room temperature. The use of $96 \%$ ethanol solvents was due to its universal properties that capable of dissolving almost all types of secondary metabolites that have low molecular weight such as flavonoids, saponins, and alcohol; non-toxic and safe to use (Pratiwi et al., 2013; Azis et al., 2014; Arifianti et al., 2014). The percentage yields ( $w / w)$ of the extracts were calculated using the formula below (Kusuma et al., 2017):

(Weight of extract/Weight of starting plant material) $\times 100 \%$

S. epidermidis was grown in $\mathrm{BHI}$ medium for $24 \mathrm{~h}$ at $37^{\circ} \mathrm{C}$ and then grown on the BAP for $24 \mathrm{~h}$ at $37^{\circ} \mathrm{C}$ (Novaryatiin et al., 2018). Antibacterial activity was performed using the disc diffusion technique, where the discs were impregnated with four variations of concentration of $1 \%, 5 \%, 10 \%$, and 15\%. The McFarland 0.5 standard was prepared and $10 \mathrm{~mL}$ were put into sterile tubes. The bacterial suspension was made by taking bacterial colonies diluted in sterile normal saline and the turbidity adjusted to $1.10^{8} \mathrm{CFU} / \mathrm{mL}$ (according to McFarland 0.5 standard). A sterile cotton swab was immersed in a standardized bacterial suspension and used to evenly inoculate on MHA plate. Then all the discs that have been immersed in ethanolic extract of Sangkareho were placed on the plates. A clindamycin antibiotic was used as positive controls with concentration variations of $1 \%, 5 \%, 10 \%$, and $15 \%$. Discs that have been immersed in clindamycin were also placed on the plate. The plate was then incubated for $24 \mathrm{~h}$ at $37^{\circ} \mathrm{C}$. The diameter of the zone of inhibition formed was measured in $\mathrm{mm}$ using a caliper. The study was repeated in triplicates for each extract and positive control.

\section{RESULTS AND DISCUSSION}

\section{The yield of the extract}

From the rendement calculation, the extraction of Sangkareho yields of $9.3 \%$ (Figure I). Value yield is related to the number of secondary metabolites that successfully attracted when the extraction process (Kusuma et al., 2017).

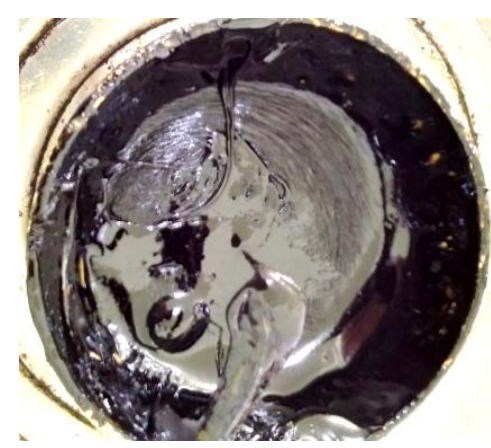

Figure I. Ethanolic Extract of Sangkareho Leaves

\section{Antibacterial activity}

In this study, clindamycin was used as positive controls. Clindamycin was chosen as a positive control because it is a narrow-spectrum antibiotic, having a sensitivity to Grampositive bacteria in the genus Staphylococcus including $S$. epidermidis which causes infection in wounds. Clindamycin is used to treat various types of bacterial infections of the skin, especially the epidermis, blood, and internal organs. The mechanism of action of clindamycin is to inhibit the synthesis of bacterial proteins by binding to the sub-unit of $50 \mathrm{~S}$ ribosome bacteria which inhibits the formation of peptide bonds (Katzung, 2009).

The diameters of inhibition zones produced by clindamycin with concentration $1 \%, 5 \%, 10 \%$, and $15 \%$ against $S$. epidermidis were $28.9 \pm 1.1 \mathrm{~mm}, 36.3 \pm 2.0 \mathrm{~mm}, 29.0 \pm 0.2 \mathrm{~mm}$, $29.9 \pm 0.8 \mathrm{~mm}$, and $31.2 \pm 0.1 \mathrm{~mm}$, respectively as presented in Table I. The diameters of inhibition zones produced by all tested concentrations of clindamycin against all tested bacteria were greater than the diameters of inhibition zones produced by ethanolic extract of Sangkareho (Figure 2).

Table I. Antibacterial Activity of Clindamycin and Sangkareho Against Staphylococcus epidermidis

\begin{tabular}{ccc}
\hline Materials & $\begin{array}{c}\text { Concentration } \\
(\%)\end{array}$ & $\begin{array}{c}\text { Diameter of Inhibition } \\
\text { Zones }(\mathrm{mm})(\text { mean } \pm S D, \\
\mathrm{n}=3)\end{array}$ \\
\hline Clindamycin & 1 & $28.9 \pm 1.1$ \\
(positive & 5 & $36.3 \pm 2,0$ \\
control) & 10 & $38.9 \pm 2.6$ \\
& 15 & $39.0 \pm 2.7$ \\
\hline Ethanolic & 1 & $7.3 \pm 0.8$ \\
extract of & 5 & $8.3 \pm 1.2$ \\
Sangkareho & 10 & $10.5 \pm 0.5$ \\
& 15 & $12.2 \pm 0.7$ \\
\hline
\end{tabular}




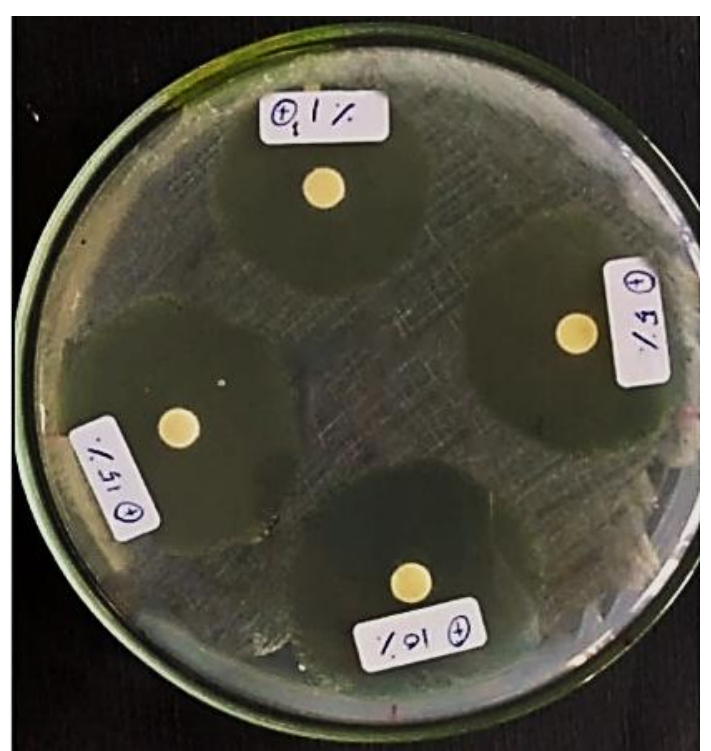

Figure 2. Antibacterial activity of clindamycin against $S$. epidermidis

The antibacterial activity test of the ethanolic extract of Sangkareho was done in triplicates. Accordingly, ethanolic extract of Sangkareho was active against S. epidermidis in all the tested concentration, whose inhibition zones were in the range of 7.3-12.2 mm (Figure 3). The inhibition zones at concentrations of $1 \%, 5 \%, 10 \%$, and $15 \%$ were $7.3 \pm 0.8$ $\mathrm{mm}, 8.3 \pm 1.2 \mathrm{~mm}, 10.5 \pm 0.5 \mathrm{~mm}$, and $12.2 \pm 0.7 \mathrm{~mm}$, respectively (Table I). The antimicrobial activities of extracts can be classified into three levels, weak activity (inhibition zone lower than $12 \mathrm{~mm}$ ), moderate activity (inhibition zone between 12 and $20 \mathrm{~mm}$ ), and strong activity (inhibition zone higher than $20 \mathrm{~mm}$ ) (Syahbazi, 2017).

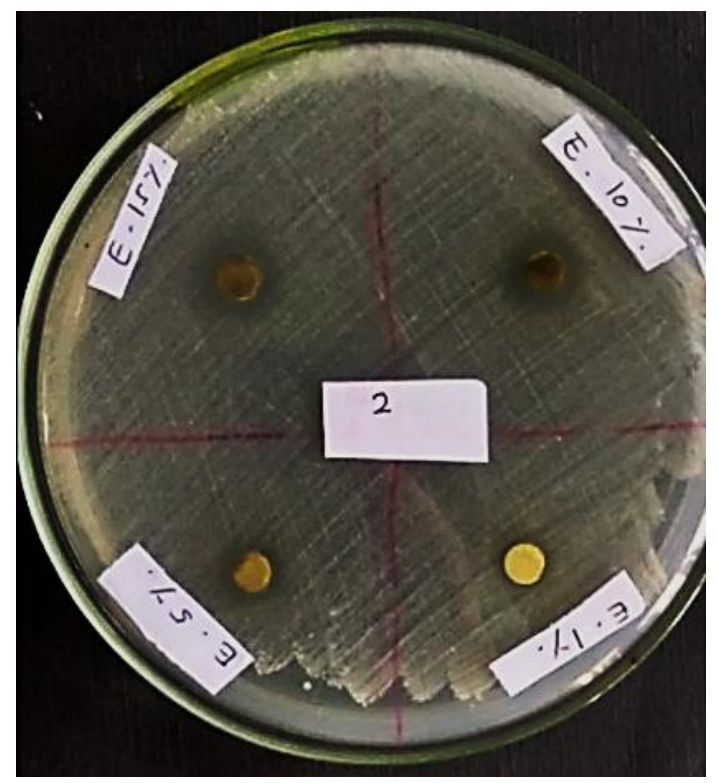

Figure 3. Antibacterial activity of ethanolic extract of sangkareho leaves against $S$. epidermidis
The previous study reported that ethanolic extract of Sangkareho leaves was active against $S$. aureus, which caused wound infection. The inhibition zones at concentrations of $1 \%, 5 \%, 10 \%$, and $15 \%$ were $1 \mathrm{~mm}, 2.7$ $\mathrm{mm}, 3.9 \mathrm{~mm}$, and $6.2 \mathrm{~mm}$ (Handayani \& Novaryatiin, 2017). It can be stated that the antibacterial activity of ethanolic extract of Sangkareho leaves against S. epidermidis is greater than that of S. aureus.

The increasing concentration of ethanolic extract of Sangkareho leaves was directly proportional to the larger diameter of the diameter of inhibition zone formed. This shows that the compounds contained in the extract can inhibit the growth of $S$. epidermidis. Based on research by Saputra (2016) regarding the pharmacognostic identification of Sangkareho leaves, it was found that Sangkareho leaves contained secondary metabolites, one of which was flavonoids. Flavonoid compounds have the potential as antibacterial.

Flavonoids are known to cause damage to the permeability of bacterial cell walls, microsomes, and lysosomes as a result of interactions between flavonoids and bacterial DNA through inhibition which results in the incorporation of non-crosslinked glucan chains into the cell membrane peptidoglycan so that it becomes a weak structure (Permatasari, 2013; Sulastrianah et al., 20I4).

\section{CONCLUSION}

Based on the results of the research that has been done, it can be concluded that the ethanolic extract of Sangkareho was able to inhibit the growth of $\mathrm{S}$. epidermidis, at concentrations of $1 \%, 5 \%, 10 \%$, and $15 \%$ with an average inhibition zone of $7.3 \pm 0.8 \mathrm{~mm}, 8.3 \pm 1.2 \mathrm{~mm}, 10.5 \pm 0.5 \mathrm{~mm}$, and $12.2 \pm 0.7 \mathrm{~mm}$. Further research is needed to obtain an antibacterial activity of the fraction of Sangkareho leaves.

\section{REFERENCE}

Arifianti, L., Oktarina, R.D., Kusumawati, I. 2014. Effect of solvent extraction type on sinesetin levels in Orthosiphon stamineus benth. EJ Planta Husada. 2(1):3.

Azis, T., Febrizky, S., Mario, A.D. 2014. The effect of type of solvents to alkaloids yield percent from salam india (Murraya koenigii) leaves. Teknik Kimia. 20:1-6.

Handayani, R., Novaryatiin, S., Valentiningtyas, W.A. 2015. Identifikasi farmakognostik tumbuhan hati tanah asal Kota Palangka Raya Kalimantan Tengah. Jurnal Surya Medika, I ( I):48-55. 
Handayani, R., Novaryatiin, S. 2017. Potensi tumbuhan hutan berkhasiat obat asal Kalimantan Tengah sebagai penghambat pertumbuhan bakteri Staphylococcus aureus. Proceeding of Rakernas \& Pertemuan Ilmiah Tahunan Ikatan Apoteker Indonesia 2017. Banten.

Hapsoh, Hasanah. 201I. Budidaya Tanaman Obat dan Rempah. Medan: USU Press.

Jawetz, E., Melnick, J.L., Adelburg, E.A. 2014. Mikrobiologi Kedokteran. Jakarta: EGC.

Katzung, B.G. dan Trevor, A.J. 2009. Buku Bantu Farmakologi. Jakarta: EGC.

Kusuma, S.A.F., Mita, S.R., Firdayani, I., Mustarichie, R. 2017. Study on the antibacterial activity of fruit extracts of klutuk banana (Musa balbisiana Colla) against Shigella dysenteriae ATCC I33 I3. Asian J Pharm Clin Res. 10(7):220-223.

Noorcahyati. 2012. Tumbuhan berkhasiat obat etnis asli Kalimantan. Balikpapan: Balai Penelitian Teknologi Konservasi Sumber Daya Alam.

Novaryatiin, S., Pratomo, G.S., Yunari, C. 2018. Uji daya hambat ekstrak etanol daun jerangau hijau terhadap Staphylococcus aureus. Borneo Journal of Pharmacy. I(I): I I-I5.

Permatasari, G.A.A.A. 2013 Daya hambat perasan daun sirsak terhadap pertumbuhan bakteri Escherichia coli. Jurnal Medicus Veterinus, 2(2): I62-169.

Pratiwi, D., Wardaningsih, S., Isnindar. 2013. The test of antioxidant activity from bawang mekah leaves (Eleutherine americana Merr.) using DPPH (2,2Diphenyl-I-Picrylhydrazyl) method. Traditional Medicine Journal. 18:9-16.

Saputra, A.K. 2016. Uji identifikasi farmakognostik tanaman sangkareho (Callicarpa longifolia Lam.) asal Kalimantan Tengah. Karya Tulis Ilmiah. Universitas Muhammadiyah Palangkaraya.

Shahbazi, Y. 2017. Antibacterial and antioxidant properties of methanolic extracts of apple (Malus pumila), grape (Vitis vinifera), pomegranate (Punica granatum L.), and common fig (Ficus carica L.) fruits. Pharmaceutical Science. 23:308-3I5.

Sulastrianah, Imran, Fitria, E.S. 20I4. Uji daya hambat ekstrak daun sirsak (Annona muricata L) dan daun sirih (Piper betle $\mathrm{L}$ ) terhadap pertumbuhan bakteri Escherichia coli. Medula. I(I):76-84. 